\title{
Induction of Abnormal Immunoglobulin Maturation and Antibody Production by Persistent Embryonic Mumps Virus Infection
}

\author{
TERRY YAMAUCHI, ${ }^{32}$ ' JOSEPH W. ST. GEME, JR., HAWLEY L. MARTIN, DOUGLAS C. HEINER, \\ AND MAX D. COOPER \\ Laboratory of Microbiologic and Immunologic Research. Department of Pediatrics. Harbor General Hospital. \\ UCLA School of Medicine, Torrance. California, and Spain Immunology Research Laboratories. Departments of \\ Immunology and Microbiology, University of Alabama Medical Center. Birmingham, Alabama, USA
}

\section{Extract}

Intramuscular inoculation of 19-day old chickens with heterologous erythrocytes elicited significantly lower levels of agglutinins in embryonically infected birds when compared with control birds (reciprocal ha titer 10 vs. 100 , respectively, $P<0.01$ ). The IgG component of this antibody was substantially less in experimental chickens, $25 \%$ vs. $70 \%$ in controls. Subsequent anamnestic antibody response in experimental birds was also significantly less than control chickens (reciprocal ha titers 25 vs. 512, respectively, $P<$ 0.02 ), with continued predominance of IgM antibody in experimental chickens $(70 \%$ IgM-ha) vs. controls $(60 \%$ IgG-ha).

Induction of cell-mediated immunity by footpad inoculation of 46-day-old birds with diphtheria-tetanus toxoid in complete Freund's adjuvant failed to discern suppression of $T$ cell function in previously infected chicks.

Before hatch, the bursae of experimental and control embryos possessed a few IgM-producing lymphoid cells in equivalent numbers. There was also no difference in the relative population of IgM-producing cells in the medullary area of bursal follicles of 7-day-old hatchling chickens, approximately 70\%. However, the mean density of $\operatorname{IgG}$-producing cells in the bursae of experimental chickens was less than that of control chickens, $10 \%$ vs. $19 \%$, respectively. Consistent with persistent embryonic viral infection and altered bursal function, only IgM-producing cells were detected in the spleens of 7-day-old experimental birds.

These observations suggest that persistent embryonic viral infection disturbs the function of bursal-dependent immunopoiesis in the avian host.

\section{Speculation}

Early and persistent embryonic mumps virus infection in the avian host results in abnormal immunoglobulin maturation and antibody production. The following mechanisms may influence the immune response in this experimental model: viral replication may directly suppress the transition of IgM-producing cells within the embryonic and hatchling bursa at the stem cell level by altering genetic expression; infection may induce the production of a bursal repressor which disturbs the transition of immunoglobulin synthesis from IgM to IgG; growth retardation may be associated with generalized diminution of immunocellular replication and function.

The embryonic and hatchling chicken provides a unique experimental model whereby one may study the ontogeny of the immune response and evaluate the separate contributions of the thymic and bursal systems to the ultimate appearance of cellular and humoral immunity (5). The bursa of Fabricius is the initial site of immunoglobulin synthesis and controls the transition of immunoglobulin $\mathrm{M}$ to immunoglobulin $\mathrm{G}$ and immunoglobulin $\mathrm{A}(2,4,23$, 26). The thymus conditions the development of lymphoid cells necessary for antigenic recognition and the initial proliferative phases of cell-mediated immunity $(7-10,12,28)$.

We have reported previously that mumps virus infection of the immature chicken embryo produces a transient decrease in the synthesis of $\operatorname{IgM}$ and a delay in the transition of Ig production to IgG (24). In this paper, we have attempted to characterize more precisely the magnitude of the avian dysgammaglobulinemia induced by mumps virus.

\section{MATERIALS AND METHODS}

\section{CHICKENS}

Fertile eggs of the white leghorn species were obtained from the Health Research Laboratory, Redmond, Washington, and the embryos were reported to be free from lymphoid leukosis, avian encephalomyelitis, CELO (chicken embryo lethal orphan), Marek's disease, Newcastle disease, infectious bronchitis, fowlpox, infectious bursal agent, and avian influenza, type A viruses.

\section{VIRUS}

Within the first $24 \mathrm{hr}$ of incubation embryos were inoculated with $10^{4} \mathrm{TClD}_{30}$ of mumps virus (strain Amaris). The biologic characteristics and method of inoculation of this strain of virus have been described before $(24,25)$. A similar volume of spent HeLa cell culture medium was inoculated into control embryos. Because infected embryos had a hatch rate of $25-50 \%$. it was necessary to inoculate 3-6 dozen embryos per experiment to harvest an adequate number of hatchling chickens. Control embryos hatched in greater numbers and 2--4 dozen embryos per experiment generally produced an equal number of surviving chickens (29).

\section{HEMAGGLUTININ $A S S \wedge Y$}

At 19 days of age, hatchling chickens were inoculated intramuscularly in the right thigh with $1 \mathrm{ml} \mathrm{5 \%}$ guinea pig erythrocytes suspended in Alsever's solution. Heparinized samples of blood were obtained 6 and 14 days later. A booster immunization of erythrocytes was administered in the left thigh at 33 days of age (14 days after the primary immunization), and a third blood sample was obtained 13 days later. Chicken plasma was heat-inactivated in a $56^{\circ}$ waterbath for $30 \mathrm{~min}$. Microtiter plates were employed and $0.05 \mathrm{ml}$ plasma was added to the initial dilution well. Calcium-magnesium-free phosphate-buffered saline (PBS), $\mathrm{pH}$ 
7.4, was pipetted in $0.025-\mathrm{ml}$ volumes into subsequent wells, allowing serial 2-fold dilutions of the plasma samples to 1:256. An additional $0.025 \mathrm{ml}$ PBS was added bringing the total volume for each well to $0.05 \mathrm{ml}$. An equal volume $(0.05 \mathrm{ml})$ of $0.1 \%$ guinea pig erythrocytes suspended in PBS was added and the mixture was incubated at $4^{\circ}$ overnight. The reciprocal of the last plasma dilution which produced hemagglutination was considered the mathematical endpoint for the calculation of the hemagglutinin (ha) titers. The absence of ha was determined by the observation of a discrete button of erythrocytes at the bottom of a well.

\section{SEPARATION OF CHICKEN PLASMA INTO IgM AND IgG HEMAGGLUTININ FRACTIONS}

Anti-chicken $\operatorname{IgM}$ and $\operatorname{IgG}$ antisera were prepared in rabbits and absorbed with $\kappa$ and $\lambda$ light chains. Plasma from a chicken hyperimmunized with sheep erythrocytes, graciously supplied by Dr. Patricia Byfield, was pretested with anti-Ig sera in order to establish the lowest concentration (greatest dilution) of chicken plasma and antisera sufficient to produce a sharp precipitin band by immuno-gel diffusion. Plasma collected from four control chickens on two separate bleedings was analyzed simultaneously. The anti-Ig reagents were used for verification of the location of IgM and IgG peaks after separation of plasma from experimental and control chickens by gel chromatography on Sephadex G-200 columns and collection of $1-\mathrm{ml}$ fractions.

The $280 \mathrm{~nm}$ optical density of each fraction was determined with a Gilford spectrophotometer 240. After localizing IgM and IgG peaks, the ha titer of each fraction was determined. Using triangulation, the percentile distribution of IgM-ha and IgG-ha was calculated for each plasma sample.

\section{CELL-MEDIATED IMMUNITY}

Modifying the technique of Cooper et al. (5), an equal volume mixture of diphtheria-tetanus toxoid (pediatric) and complete Freund's adjuvant was inoculated in $0.5-\mathrm{ml}$ volumes into the footpad of 46-day-old chickens with a number 23-gauge needle. The toxoid preparation contained 28-35 Lf of diphtheria toxoid and 14-20 Lf of tetanus toxoid. Two weeks after footpad sensitization, the wattles of the male birds were inoculated with undiluted toxoid. Using a 1.0-ml syringe and number 26-gauge needle, $0.1 \mathrm{ml}$ toxoid was injected into the mesial side of the left wattle and $0.1 \mathrm{ml}$ sterile saline was injected into the right wattle. The thickness of the wattles was measured at 24 and $48 \mathrm{hr}$ after inoculation.

\section{IMMUNOFLUORESCENT STUDIES}

On days 14, 16, 18, and 20 of embryonic incubation, the bursa and spleen were dissected from three experimental and three control chickens and fixed in $95 \%$ alcohol at $4^{\circ}$, overnight. The tissues were transferred to absolute alcohol at $4^{\circ}$, packed in Dry Ice and shipped under code to Birmingham. At 7 days post-hatch, the bursa and spleen were removed from eight experimental and eight control chickens and handled in an identical fashion. In Birmingham, the tissues were processed using the paraffin embedding technique described by Sainte-Marie (21) and analyzed for Ig-producing cells using rabbit anti-chicken IgM and IgG antisera and indirect immunofluorescent microscopy. The bursae of experimental and control chickens were assessed for the mean percentage of the medullary area of follicles which was diffusely stained.

\section{RESULTS}

\section{CHICKENS}

Although 3 dozen embryonated eggs were inoculated with mumps virus, only 7 eggs produced hatchling chickens. Two dozen embryonated eggs inoculated with spent HeLa cell culture medium yielded 10 controls. At hatch and regular intervals thereafter, experimental and control chickens were weighed on a Sartorius analytic balance. Throughout the study period the 7 experimental chickens weighed less than the 10 controls. At 7 weeks the mean weight of the experimental birds was $386 \pm 12.5 \mathrm{~g}$, significantly less than the weight of control birds, $446 \pm 21.8 \mathrm{~g}(P<0.004$, Student's $t$-test; Fig. 1).

\section{HEMAGGLUTININ ASSAY}

The mean ha titer of six experimental chickens was significantly lower 6 days after immunization when compared with the mean of nine controls ( 10 and 100 , respectively, $P<0.01$, Student's $t$-test; Fig. 2). At the same time there was also a delay in transition of $19 \mathrm{~S}$ to $7 \mathrm{~S}$ antibody in the experimental group, since only $25 \%$ of the ha was IgG. In the control chickens IgG constituted $70 \%$ of the ha 6 days after immunization. At 14 days after primary immunization there was no significant difference between the ha titers of the experimental and control chickens. At this time the percentage of $\lg G$ ha for both groups was also the same. Thirteen days after the booster erythrocyte inoculation, experimental chickens again demonstrated significantly less ha antibody than controls (25 vs. $512, P<0.02$, Student's $t$-test) and persistent depression of the $7 \mathrm{~S}$ antibody. In the experimental chickens $30 \%$ of the ha was $7 \mathrm{~S}$ vs. $60 \%$ in the controls.

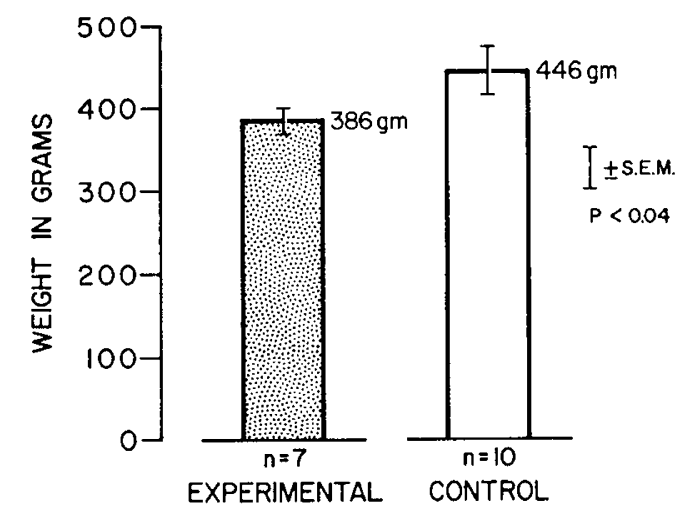

Fig. 1. Persistent embryonic mumps virus infection growth retardation. Comparison of the mean weight in grams of 7 experimental and 10 control chickens at 7 weeks of age.

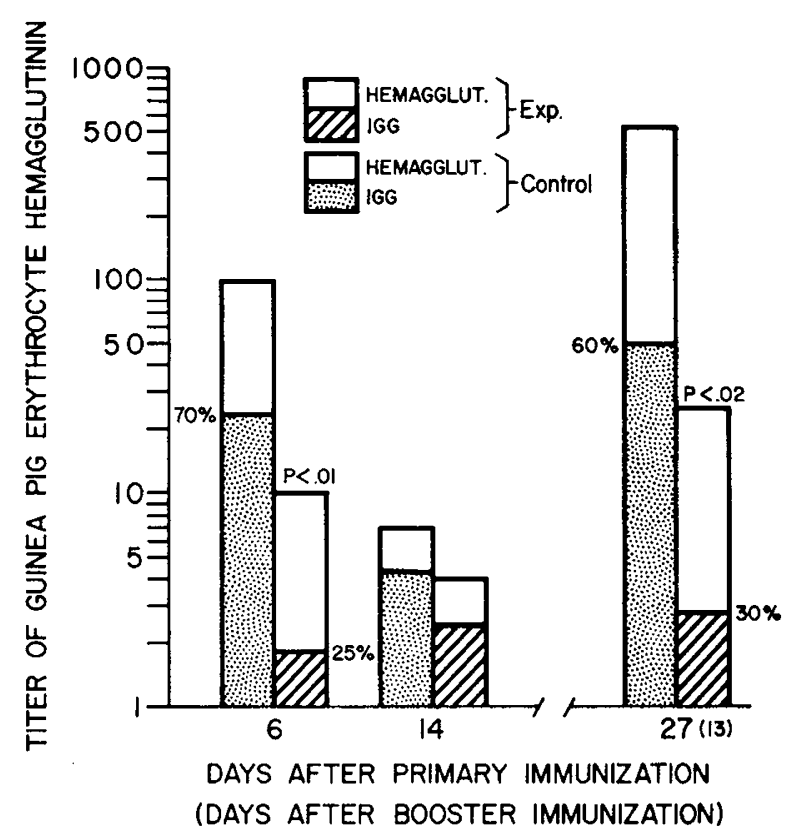

Fig. 2. Illustration of mean hemagglutinin titers to guinea pig erythrocytes of experimental and control chickens obtained 6 and 14 days after primary immunization and 13 days (in brackets) after booster immunization. Transition of immunoglobulin $M$ to immunoglobulin $G$ is delayed. 


\section{CELL-MEDIATED IMMUNITY}

Wattle reaction to diphtheria-tetanus toxoid was compared in three experimental and four control chickens. At $24 \mathrm{hr}$ the experimental chickens had a mean wattle thickness of $3.2 \pm .5 \mathrm{~mm}$ and the controls $2.7 \pm 1.3 \mathrm{~mm}$. At $48 \mathrm{hr}$ the experimental chickens had a mean wattle thickness of $1.7 \pm 0.3 \mathrm{~mm}$ and the controls $2.0 \pm 1 \mathrm{~mm}$. These differences in wattle reaction between experimental and control birds were not significant.

\section{IMMUNOFLUORESCENT STUDIES}

During the 6 days prior to hatch a few IgM-producing cells were detected in the bursae of both experimental and control embryos. There was no difference in the relative population of IgM-bearing cells in the medullary area of follicles from the bursae of 7-day-old experimental and control chickens (approximately $70 \%$ ). Although the density of immunofluorescence varied from bird to bird the population of IgG-producing cells in the bursae of 7-day-old experimental chickens was substantially reduced. Ten percent of the medullary areas of bursal follicles from experimental chickens had diffuse staining for IgG. Three virus-positive chickens had no IgG-staining in the medullary areas. Diffuse IgG staining was detected in $19 \%$ of the medullary areas of bursal follicles from control chickens. A few IgM-producing cells were observed only in the spleens of infected chickens.

\section{DISCUSSION}

Cooper (5), Thorbecke (26), Cain (3), and others (16, 17) have elegantly delineated the development of immunologic competence in the avian host. Experimental ablation or injury to the thymus and/or bursa produces a spectrum of immunologic deficiency states $(9,11,13-15,20)$.

In our experimental model of embryonic viral infection, $\mathrm{T}$ cell function was normal. The primary alteration of immunopoietic development was restricted to the bursal system and characterized by the attenuation of the maturation of bursal IgM- to IgG-producing cells, antibody response, and the transition of $\operatorname{IgM}$ to $\operatorname{IgG}$ hemagglutinin. After primary immunization, normal levels of total and IgG antibody were ultimately reached by 2 weeks. However, this sensitive pattern of altered immunopoiesis was recapitulated by secondary immunization. As reported previously (24), after hatch, levels of plasma IgM and IgG were decreased in chickens which had been infected with mumps virus during early embryogenesis. Consistent with the antibody response in these experiments, disturbed Ig synthesis was transient, since IgM production in experimental chickens equalled that of normal birds by 2 months of age and IgG levels were eventually restored to normal by 11 months (24).

Faragher et al. (6) inoculated 1-day-old chickens with infectious bursal agent, a virus which destroys lymphatic tissue in the bursa, and significantly reduced both primary and secondary serologic responses to Newcastle disease virus vaccine. Experimental infection of chickens with infectious bursal agent at 21 days of age did not deter antibody response and demonstrated the age-dependent relationship between bursectomy and immunocompetence. Once immunologically competent cells have migrated from bursa, destroying bursal lymphocytes has little impact upon the immune system. Faragher and coworkers (6) believed that earlier embryonic viral infection would further suppress the humoral response. In our experiments, chicken embryos were infected within the first $24 \mathrm{hr}$ of incubation.

The normal ontogenic development of immunoglobulins requires that IgM-producing cells shift their Ig product to $\mathrm{IgG}$. The mechanism of this transition is unclear. The major consequence of embryonic viral infection is the inability of $\mathrm{IgM}$-producing cells to switch to IgG synthesis. Mumps virus can be recovered from several embryonic organs throughout the last half of incubation (29). Although highest titers of virus are found in the heart, at midembryonic incubation the bursa of Fabricius also contains high titers of virus, but these levels decline by hatch. Viral infection may cause direct suppression of Ig transition by reorientation of cellular metabolism such that nucleic acid synthesis perquisite to normal Ig and antibody production is either impaired or an abnormal transcript is made. Bursal cells cultivated from previously infected 12-day-old embryos demonstrate an increased metabolic rate as measured by incorporation of radiolabeled precursors (29), coinciding with the imitation of Ig synthesis in ovum (3). This metabolic alteration is unique to the bursa, since other organs are unaffected. With the increased production of nucleic acids and protein one might postulate the evolution of a repressor substance. Thorbecke et al. (26) hypothesized that bursal cells synthesize a "hormone" which stimulates differentiation of stem cells into Ig-producing cells. In our model, embryonically infected bursal cells might instead synthesize a substance which represses differentiation of the more primitive stem cell, or blocks the production of the stem cell stimulator or hormone. Growth retardation occurs in chickens embryonically infected with mumps virus $(24,27)$ and has been attributed to a diminution in the cell size of organs (29). During the full post-hatch period of these immunologic studies, experimental chickens were smaller than control birds. Depression of humoral antibody responses with growth retardation has been demonstrated by a number of investigators $(1,12,18,22)$ and probably reflects impaired replication of immunopoietic tissues.

One or more of the following mechanisms may influence the immune response in this early and persistent embryonic viral infection: viral replication may directly suppress the transition of IgM-producing cells within the embryonic and hatchling bursa at the stem cell level by altering genetic expression; infection may induce the production of a bursal repressor which disturbs the transition of immunoglobulin synthesis from IgM to IgG; finally, growth retardation itself may be associated with diminished immunocellular replication and function.

\section{SUMMARY}

Chicken embryos persistently infected with mumps virus exhibit delayed maturation of IgM-producing lymphoid cells to IgG-producing cells in their bursae of Fabricius after hatch. Primary and secondary antibody response to heterologous erythrocytes is attenuated in previously infected chickens and characterized by a delay in transition from IgM to IgG antibody. Cell-mediated immunity is unaffected by embryonic viral infection. Several mechanisms may be involved, including a direct effect of virus on bursal tissue, the induction of a bursal repressor substance, or simply the general impact of growth retardation.

\section{REFERENCES AND NOTES}

1. Adlard, B. P. F., Hamid, J., Labedz, R., and McFarlane, H.: Uptake of $\left[{ }^{3} \mathrm{H}\right]$ corticosterone and the immune response in growth-retarded rats. Pediat. Res., 7: 833 (1973).

2. Benedict, A. A., Brown, R. J., and Hersh, R. T.: The temporal synthesis and some chromatographic and ultracentrifugal characteristics of chicken antibodies. J. Immunol., 90: 399 (1963).

3. Cain, W. A., Cooper, M. D., Van Alten, P. J., and Good, R. A.: Development and function of the immunoglobulin-producing system. J. Immunol., 102: 671 (1969).

4. Cooper, M. D., Lawton, A. R., and Kincade, P. W.: A two-stage model for development of antibody-producing cells. Clin. Exp. Immunol, l I: 143 (1972).

5. Cooper, M. D., Peterson, R. D. A., South, M. A., and Good, R. A.: The functions of the thymus and the bursa system in the chicken. J. Exp. Med., 123: 75 (1966).

6. Faragher, J. T., Allan, W. H., and Cullen, G. A.: Immunosuppressive effect of the infectious bursal agent in the chicken. Nature New Biol., 73: 118 (1972).

7. Good, R. A., Dalmasso, A. P., Martinez, C., Archer, O. K., Pierce, J. C., and Papermaster, B. W.: The role of the thymus in development of immunologic capacity in rabbits and mice. J. Exp. Med., 116: 773 (1962).

8. Good, R. A., and Gabrielsen, A. E. (Eds.): The Thymus in Immunobiology (Hoeber-Harper, New York, 1964).

9. Good, R. A., and Gabrielsen, A. E.: The thymus and other lymphoid organs in the development of the immune system. In: Rapaport-Dansset: Human Transplantation, p. 526 (Grune and Stratton, Inc., New York, 1968).

10. Good, R. A., and Papermaster, B. W.: Ontogency and phylogeny of adaptive immunity. Advan. Immunol., 4: 1 (1964).

11. Graetzer, M. A., Wolfe, H. R., Aspinall, R. L., and Meyer, R. K.: Effect of 
thymectomy and bursectomy on precipitin and natural hemagglutinin and production in the chicken. J. Immunol., 90: 878 (1963).

12. Harris, T. N., Rhoads J., and Stokes, J. J.: A study of the role of the thymus and spleen in the formation of antibiotics in the rabbit. J. Immunol., 58: 27 (1948).

13. Humphrey, J. H., Parrott. D. M. V., and East, J.: Studies on globulin and antibody production in mice thymectomized at birth. J. Immunol., 7: 419 (1964).

14. Isakovic, K., and Jankovic, B. D.: Role of the thymus and the bursa of Fabricius in immune reactions in chickens. II. Cellular changes in lymphoid tissues of thymectomized, bursectomized and normal chickens in the course of first antibody response. Int. Arch. Allergy Appl. Immunol., 24: 296 (1964).

15. Jankovic, B. D., and Isakovic, K.: Role of the thymus and bursa of Fabricius in immune reactions in chickens. I. Changes in lymphoid tissues of chickens surgically thymectomized at hatching. Int. Arch. Allergy Appl. Immunol., 24: 278 (1964).

16. Kincade, P. W., and Cooper, M. D.: Development and distribution of immunoglobulin-containing cells in the chicken. J. Immunol., 106: 371 (1971).

17. Lawton, A. R., Kincade, P. W., and Cooper, M. D.: Sequential expression of germ line germs in development of immunoglobulin class diversity. Fed Proc., 34: 33 (1975)

18. Lopez, V., Davies, S. D., and Smith J. J.: Studies in infantile marasmus. IV. Impairment of immunologic responses in the marasmic pig. Pediat. Res., 6: 779 (1972).

19. Mueller, A. P. Wolfe, H. R., and Meyer, R. K.: Precipitin production in chickens. XXI. Antibody production in bursectomized chickens and in chickens injected with 19-nortestosterone on the fifth day of incubation. J. Immunol., 85 : 172 (1960).

20. Mueller, A. P.. Wolfe, H. R., Meyer, R. K., and Aspinall, R. L.: Further studies on the role of the bursa of Fabricius in antibody production. J. Immunol., 88: 354 (1962).

21. Sainte-Marie, G. J.: A paraffin embedding technique for studies employing immunofluorescence. Histochem. Cytochemi., 10: 250 (1962).
22. Smythe, P. M., Schonland, M., Brereton-Stites, G. G., Coovadia, H. M., Grace H. J., Loening, W. E. K., Mafoyane, A., Parent, M. A., and Vox, G. H.: Thymolymphatic deficiency and depression of cell-mediated immunity in protein-calorie malnutrition. Lancet, $i: 939$ (1971).

23. Stecher, V. J., and Thorbecke, G. J.: Sites of formation of $\mathrm{C}_{3}{ }_{3}$. III. ${ }^{\mathrm{B}} \mathrm{IC}$ and immune globulin formation by tissues from serum-free and normal animals of various ages. Immunology, I2: 475 (1967).

24. St. Geme, J. W., Jr., Davis, C. W. C., Peralta, H. J., Farias, N. E., Yamauchi, T., and Cooper, M. D.: The biologic perturbations of persistent embryonic mumps virus infection. Pediat. Res., 7: 541 (1973).

25. St. Geme, J. W. Jr., Peralta, H., Farias, E., Davis, C. W. C., and Noren, G. R.: Experimental gestational mumps virus infection and endocardial fibroelastoris. Pediatrics, 48: 821 (1971).

26. Thorbecke, G. J., Warner, N. L., Hochwald, G. M and Ohanian, S. H. Immune globulin production by the bursa of Fabricius of young chickens. Immunology. 15: 123 (1968).

27. Williamson, A. P., Blattner, R. J., and Simonsen, L.: Cataracts following mumps virus in early chick embryos. Proc. Soc. Exp. Biol. Med., 96: 224 (1957).

28. Wistenholme, G. E. W., and Porter, R. (Eds.): Some Observations on Immunologic Response in the Thymus: Experimental and Clinical Studies (Little, Brown and Company, Boston, 1966).

29. Yamauchi, T., St. Geme, J. W., Jr., Oh, W., and Davis, C. W. C.: The biological and biochemical pathogenesis of mumps virus-induced embryonic growth retardation. Pediat. Res., 9: 30 (1975).

30. The authors wish to express their gratitude to Ms. Jenny Keshishian and Ms. Janice White in preparing this manuscript.

31. Portions of this paper were presented at the annual meeting of the American Pediatric Society and the Society for Pediatric Research, May 2, 1974 Washington, D.C.

32. Requests for reprints should be addressed to: T. Yamauchi, M.D., Arkansas Children's Hospital, 804 Wolfe St.. Little Rock, Ark. 72201 (USA).

33. Accepted for publication May 31, 1976.
Alanine aminotransferase arginase

fetus glutamate dehydrogenase liver thymidine kinase

\title{
Glutamate Dehydrogenase, Alanine Aminotransferase, Thymidine Kinase, and Arginase in Fetal and Adult Human and Rat Liver
}

\author{
ANNEMARIE HERZFELD, ${ }^{(19)}$ VICTOR M. ROSENOER, AND SUZANNE M. RAPER \\ Department of Biological Chemistry, Harvard Medical School: Cancer Research Institute, New England Deaconess \\ Hospital; Department of Gastroenterology, Lahey Clinic Foundation, Boston, Massachusetts, USA
}

\section{Extract}

In fetal livers of both man and rat thymidine kinase activity was 12 times higher than in the adult, glutamate dehydrogenase and arginase were present at $20-50 \%$ of their adult values, whereas alanine aminotransferase activity was only an insignificant fraction of that in the adult. Although the developmental changes for the four enzymes were quantitatively similar in both species, qualitatively there were some significant differences.

In adult human liver, glutamate dehydrogenase activity was distributed almost equally between the cytosol and particles; the concentration of only the soluble enzyme increased after birth. In rat liver, glutamate dehydrogenase remained exclusively a particulate enzyme. The soluble hepatic alanine aminotransferase activity rose in both species after birth (from less than $2 \mathrm{U} / \mathrm{g}$ to $41-57 \mathrm{U} / \mathrm{g}$, respectively). Thymidine kinase was wholly soluble in the fetal livers; only in adult human liver was additional activity (at least
$50 \%$ of the total) found in the particles. Arginase isozymes, identical and apparently the same single isozyme in fetal and adult rat liver, show an ontogenetic change in man. A shift from a single form, common to human fetal liver and fetal kidney, to at least two variants in adult human liver, indicates another complexity of the fully differentiated liver in man.

\section{Speculation}

It is unlikely that the occurrence of particulate thymidine kinase and soluble glutamate dehydrogenase in man is restricted to liver. Their relatively late appearance in life suggests that their further study would be of interest to both ontogeny and phylogeny.

The developmental formation of thymidine kinase (EC. 2.7.1.75), glutamate dehydrogenase (EC. 1.4.1.2), arginase (EC. 